\title{
EFFECT OF NITROGEN FORMS AND RATES ON SOME HEAVY METALS AVAILABILITY AND RICE PRODUCTIVITY UNDER WASTEWATER IRRIGATION \\ El Sharkawi, H. M. ${ }^{1}$ and B. A. Zayed ${ }^{2}$ \\ 1- The Center Laboratory for Agriculture Climate (CLAC), Agriculture Research Center, Giza \\ 2- Rice Research \& Training Center (RRTC), FCRI, ARC Sakha, 33717, Kafr El Sheikh, Egypt
}

\begin{abstract}
Water shortage in rice cultivation area in Egypt pushed rice farmer to use poor quality water in rice irrigation. Using the correct nitrogen form with the proper rate might be coping with the condition and possible heavy metals in such water. Two field experiments were conducted in 2010 and 2011 seasons at The Farm of Sakha Agriculture Research Station, Kafr-El Sheikh Governorate, Egypt. The soil texture was clayey. EC was $1.5 \mathrm{dSm}^{-1}$. The study aimed to find out the effect of various nitrogen forms; Urea, ammonium nitrate and ammonium sulfate with varying nitrogen levels of 0 , 109, 146 and $219 \mathrm{~kg} \mathrm{~N}$ ha $^{-1}$ on Nickel (Ni), Cadmium (Cd) and Lead $(\mathrm{Pb})$ concentrations in soil, rice straw and rice grain as well as yield and yield components of Giza 178 rice variety under poor quality water. The chemical analysis of irrigation water was as following, $\mathrm{Ni} 0.28,0.27, \mathrm{Cd} 0.15,0.17 \mathrm{~Pb} 0.34,0.36 \mathrm{mg} \mathrm{kg}^{-1}$, ECw 2.66, 2.71 and $\mathrm{pH} 8.15,8.2$ in the first and second seasons, receptively. Results indicated that the tested nitrogen forms and rate significantly affected the concentration of above-mentioned heavy metals, yield and yield components in both seasons. Ammonium sulfate was more efficient than other two nitrogen forms in minimizing heavy metals concentration in soil or rice plants and in enhancing yield and yield components under such poor quality water. The worst nitrogen form was ammonium nitrate regarding heavy metals concentration in plant or soil as well as yield and yield components of rice. Increasing nitrogen rate negatively affected the availability of heavy metals in soil, and their concentration in straw and grain of rice in both seasons. Furthermore, the increase nitrogen level (up to $146 \mathrm{~kg} \mathrm{ha}^{-1}$ ) significantly improved yield and yield components of rice in both seasons.
\end{abstract}

\section{INTRODUCTION}

Heavy metals are found ubiquitously in both polluted and unpolluted waters. Heavy metals are toxic to higher plants by causing oxidative stress, displacing other essential metals in plant pigments or enzymes, which cause disturbance in the function and of many metabolic processes, and finally reduce the growth and yield (Wang et al., 2003). Moreover, toxic heavy metals enter the food chain due to uptake and accumulation by crops which are posing a potential threat to human health.

Nitrogen ( $\mathrm{N}$ is an important component of many structural, genetic and metabolic compounds in plants and of the total nutrients absorbed by plant roots $(80 \%$ is contributed by nitrogen). It is taken up by plants through the two forms of ammonium $\left(\mathrm{NH}_{4}{ }^{+}\right)$and nitrate $\left(\mathrm{NO}_{3}{ }^{-}\right)$, and some times $\mathrm{NO}_{3}{ }^{-}$ is also reduced in plants to $\mathrm{NH}_{4}{ }^{+}$for assimilation into amino acid, proteins and then nucleic acid. For better crop growth, a combination of ammonium $\left(\mathrm{NH}_{4}{ }^{+}\right)$ and nitrate $\left(\mathrm{NO}_{3}{ }^{-}\right)$forms is preferred (Frechilla et al., 1999). One of the 
possible mechanisms to minimize heavy metals content in cereals and legumes is improving $\mathrm{N}$ nutrition. Rhizosphere chemistry, especially $\mathrm{pH}$, is very important in determining the availability and absorption of nutrients and metals including Cd from soil (Oborn et al. 1995 Jansson and Oborn 2000). Roots have a profound influence on soil pH. Rhizosphere acidification occurs as a result of $\mathrm{NH}_{4}{ }^{+}$nutrition due to the release of protons $\left(\mathrm{H}^{+}\right)$by root cells or nitrification of $\mathrm{NH}_{4}{ }^{+}$, and this induced acidification can promote mobilization of a localized metals like Cd (Zaccheo et al. 2006, Loosemore et al., 2004). The type of $\mathrm{N}$ fertilizers applied will determine whether decrease or increase in heavy metal uptake with its application. Compared to $\mathrm{NH}_{4}^{+}$fertilizers, containing fertilizers $\mathrm{NO}_{3}{ }^{-}$could enhance $\mathrm{Cd}$ uptake due to a decrease in soil $\mathrm{pH}$. However, the effect of counter ions in fertilizers like $\mathrm{Ca}$ in $\mathrm{Ca}\left(\mathrm{NO}_{3}\right)_{2}$ cannot be over looked. If applied at high rates, $\mathrm{Ca}$ in fertilizers could replace $\mathrm{Cd}$ present on soil particles, resulting in higher $\mathrm{Cd}$ concentration in the soil solution. However, this additive effect of counter ions like $\mathrm{Ca}$ on increased solubility and uptake of $\mathrm{Cd}$ is only possible at higher $\mathrm{pH}$. At lower $\mathrm{pH}$, the major effect on increased $\mathrm{Cd}$ uptake from soil would be of $\mathrm{NH}_{4}{ }^{+}$leading to a decrease in soil pH (Nadeem et al., 2010). In contrast to many researchers, Muhammad et al. (2005) stated that the treated rice plant with $\left(\mathrm{NH}_{4}\right)_{2} \mathrm{SO}_{4}$ growing under contaminated soil with heavy metals performed better regarding photosynthesis, growth and yield and yield components as well as less content of heavy metals particularly $\mathrm{Cd}$ rather than those treated by $\mathrm{NH}_{4} \mathrm{NO}_{3}$ or $\mathrm{Ca}\left(\mathrm{NO}_{3}\right)_{2}$. In addition Xie et al.(2009) recently investigated the effect of $\mathrm{N}$ form $\left(\mathrm{NH}_{4} \mathrm{NO}_{3}\right)$ on growth and uptake of $\mathrm{Cd}$ and $\mathrm{Zn}$ by Thlaspi caerulesscens in hydroponics and rhizobox experiments and found that plants fed $\mathrm{NO}_{3}{ }^{-}$accumulated much more $\mathrm{Cd}$ than plants supplied with $\mathrm{NH}_{4}{ }^{+}$, even though the rhizosphere $\mathrm{pH}$ was lower in plants treated with $\mathrm{NH}_{4}^{+}$. This $\mathrm{NO}_{3}{ }^{-}$-induced heavy metal accumulation was speculated with the increase in organic acid exudation due to the accumulation of $\mathrm{NO}_{3}{ }^{-}$at the root surface. These contrasting results could also be related to the plant species used in the various experiments. Heavy metal concentration in wheat grain would decrease due to the dilution effect by binding to some protein molecules as more biomass production sequesters more heavy metal in vegetative parts and very little moves into the grain (Landberg and Greger, 2003). But Wangstrand et al. (2007) claimed that with application of a higher rate of $\mathrm{N}$ not to enhance biomass production but increase protein content of bread wheat grain, more heavy metal might be accumulated in plants. The time of $\mathrm{N}$ application is also important, because an extra dose of $\mathrm{N}$ applied at the vegetative stage enhance biomass production; however, during the grain filling stage, the application of an extra dose of $\mathrm{N}$ increase grain heavy metal concentration similar as $\mathrm{NH}_{4}{ }^{+}$fertilization increases the availability of metals ions due to soil acidification (Zaccheo et al. 2006). So, heavy metal contaminated soils, more $\mathrm{N}$ application should be done at the vegetative stage to increase biomass production, while high $\mathrm{N}$ doses during the grain filling stage to increase protein content should be avoided. This strategy can reduce the heavy metal accumulation in grain. 
Pankovic et al. (2000) performed an experiment to analyze the effect of $\mathrm{N}$ nutrition on photosynthesis in Cd-treated sunflower plants with three low levels of $\mathrm{Cd}\left(0.5,2\right.$ and $\left.5 \mathrm{mmol} \mathrm{m}^{-3}\right)$ in combination with three $\mathrm{N}$ treatments (2, 7.5 and $10 \mathrm{mmol} \mathrm{N} \mathrm{m}^{-3}$ ). He also, concluded that $\mathrm{N}$ supply could be manipulated as a means of decreasing heavy metal toxicity to plants but optimum $\mathrm{N}$ to $\mathrm{Cd}$ ratios must be determined for specific plant species and growth conditions in which the optimum nitrogen rate was $7.5 \mathrm{~mol} \mathrm{~m}^{-3}$. Ammonium ions cause cell membrane potential depolarization, which results in the influx of $\mathrm{NH}_{4}{ }^{+}$into the cytoplasm of the root cells (Zaccheo et al., 2006). The increase of dramatically increase $\mathrm{NH}_{4}$ uptake and reduces the $\mathrm{Cd}$ uptake by cells. But the mentioned mechanism increased the translocation of $\mathrm{Cd}$ from root to shoot in sunflower plants possibly due to lack of a detoxification mechanism (Zaccheo et al., 2006). However, activities of superoxide dismutase (SOD) and peroxidase (POD) increased in the case of $\mathrm{NH}_{4}$ nutrition, which is considered a protective mechanism against stress. Peroxidase is also involved in lipids biosynthesis which acts as a physical barrier against heavy metals (Jalloh et al., 2009). On the other hand, in plants fed with $\mathrm{NO}_{3} 3$ most of the $\mathrm{Cd}$ accumulated in roots due to the detoxification mechanism (Zaccheo et al., 2006). Furthermore, Jalloh et al. (2009) in a pot experiment found that $\mathrm{NH}_{4} \mathrm{SO}_{4}$ gave the highest value of rice growth, yield components and grain yield as compared with other forms. As well as a higher heavy metal concentration and less $\mathrm{N}$ accumulation in plants treated with $\mathrm{NO}_{3}-\mathrm{N}$, and the opposite results in the case of $\mathrm{NH}_{4}{ }^{+}$treatment. Observation of plants indicated antagonistic interactions between $\mathrm{NH}_{4}{ }^{+}$and $\mathrm{Cd}$, and synergetic interactions between $\mathrm{NO}_{3}{ }^{-}$and $\mathrm{Cd}$. An increase in SOD and POD activities was also more significant in plants treated with $\mathrm{NH}_{4}{ }^{+}$, which is considered a protective mechanism against Cd stress. The authors argued that $\mathrm{Cd}$ stress could be alleviated by choosing a specific form of $\mathrm{N}$ fertilizer.

Milton et al. (2009) stated that Ni content in both root and shoots was greater in ammonium nitrate-grown rice plants rather than ammonium sulfate or urea. Also, they indicated that the omission of either Mo or Ni led to a decrease in urease activity, independent of $\mathrm{N}$ source. Nitrate reductase activity increased in nutrient solutions without $\mathrm{Ni}$, although $\mathrm{NO}_{3}{ }^{-}$increased. Furthermore, Makino (2007 and Orathai et al.(2010) reported that under rice submergence condition the heavy metals concentrations were reduced by washing, leaching and by sulfur sedimentation resulted in decrease heavy metals content in rice grains. Still, further research is needed to fully understand how $\mathrm{N}$ nutrition plays an important role to minimize heavy metals accumulation in plants, under different $\mathrm{N}$ levels.

\section{MATERIALS AND METHODS}

\section{Site and Experimental design}

Two field experiments were conducted during summer seasons of 2010 and 2011 at farm of Sakha Agricultural Research Station, Kafr el sheikh city $\left(31^{\circ} \mathrm{N}, 31.1^{\circ} \mathrm{E}\right)$ at the tail of the Nile River. Three forms of nitrogen were 
applied in the form of Ammonium sulfate $\left(\mathrm{NH}_{4}\right)_{2} \mathrm{SO}_{4}$, Ammonium nitrate $\left(\mathrm{NH}_{4}\right.$ $\mathrm{NO}_{3}$ ) and Urea. Each nitrogen source was applied in three levels (109, 164 and $219 \mathrm{~kg} \mathrm{~N} \mathrm{ha}^{-1}$ ). There were a total of 12 treatments [i.e. (three forms of nitrogen $X$ three levels of nitrogen and zero application]. Forty eight plots (counting 12 treatments replicated 4 times) were arranged into a split-plot design. The rice (Giza 178) seeds were sown in the last week of April in both seasons for nursery culture. Each plot area was $12 \mathrm{~m}^{2}$. A basal dose of phosphorus was applied during land preparation at the rate of $36 \mathrm{~kg} \mathrm{P}_{2} \mathrm{O}_{5}$ ha${ }_{1}^{1}$ as $\mathrm{Ca}\left(\mathrm{H}_{2} \mathrm{PO}_{4}\right)_{2}(15.5 \%)$ and zinc was added at the rate of $24 \mathrm{~kg} \mathrm{Zn} \mathrm{SO}$ ha $^{-1}$ as $\mathrm{ZnSO}_{4}$ in dry soil. Nitrogen was split-applied; 2/3 was incorporated before the first irrigation and $1 / 3$ was applied at panicle initiation stage. After 25 days of the nursery, $3-5$ seedlings were transplanted per hill at a spacing of $20 \times 20 \mathrm{~cm}$. Results of soil testing are presented in Table 1 . Water samples were taken during the growth period and the chemical characteristics of irrigation water were determined according to the procedures of Klute, 1986 (Table 1).

\section{Soil analyses}

Prior to the experiment, the soil was sampled from the plowed layer (20 $\mathrm{cm}$ depth), air -dried and passed through a 2-mm sieve. Soil texture was determined by the pipette method. Soil texture was determined by the modified Walkley and Black method as described by Allison, 1965. Total N was measured using kjeldehl method (Bremner and Mulvaney, 1982) water soluble phosphorus was determined colorimetrically by a spectrophotometer and the content of water soluble $\mathrm{K}$ were determined using an atomic absorption spectrophotometer (AAS). The $\mathrm{pH}$ was measured using a $\mathrm{pH}$ glass electrode in $\mathrm{H}_{2} \mathrm{O}$ at a water:solid ratio of $1: 2.5$, and the electrical conductivity of the solution (1:5) was measured using an electrical conductivity meter ( Richards, 1954) the concentration of heavy metals were determined in a diethlenetriaminepentaacetic acid ( DTPA) extract using an AAS. A hundred $\mathrm{mL}$ of $0.05 \mathrm{M}$ DTPA per $10 \mathrm{~g}$ of soil was shaken for 2 hours at room temperature, and then the solution was filtered (Lindsay and Norvell, 1978). The selected properties are given in Table 1.

\section{Sampling and chemical analysis}

Crop was harvested in the $1^{\text {st }}$ week of October from each treatment within the central area of $5 \mathrm{~m}^{2}(2.5 \times 2 \mathrm{~m})$ to determine the grain yield (ton ha-1). Also, yield contributing parameters such as number of panicle hill-1, panicle length, panicle weight, number of filled grains panicle ${ }^{-1}$ and number of unfilled grains were measured. Three hills of mature rice plants from each plot were also sampled for plant chemical analyses. Samples of shoot and grain of rice plant were selected to determine heavy metals concentration. The sampled plants were washed in tap water and deionized water in the order, then separated into straw and grains, over-dried in an oven at $80^{\circ} \mathrm{C}$ to constant weight was done, then the grains were milled into powder for measurement of heavy metals content. At harvest time, soil samples were taken from paddy soil $(0-30 \mathrm{~cm})$ for determining available Nickel $(\mathrm{Ni})$, Cadmium ( $\mathrm{Cd})$ and Lead $(\mathrm{Pb})$. The sampled soils were dried in an aircirculating room, and then were treated to remove stones and plant residues, 
ground with wood grinder and passed through a $2 \mathrm{~mm}$ nylon sieve. The sieved samples were collected and stored in plastic bags for measurement of $\mathrm{pH}$ and extractable heavy metals content.

Table 1: Chemical analysis of the experimental field soil and the used irrigation water

\begin{tabular}{|c|c|c|c|c|}
\hline \multirow{2}{*}{ 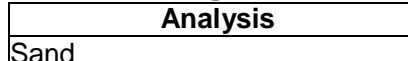 } & \multirow[t]{2}{*}{ Unit } & \multirow{2}{*}{$\begin{array}{c}\text { Amount } \\
11.59\end{array}$} & \multicolumn{2}{|c|}{ Irrigation water } \\
\hline & & & 2010 & 2011 \\
\hline Silt & $\%$ & 32.93 & - & - \\
\hline Clay & $\%$ & 55.48 & - & - \\
\hline Texture class & $\%$ & clayey & - & - \\
\hline EC & $\mathrm{dSm}^{-1}$ & 1.5 & 2.66 & 2.71 \\
\hline & - & 7.52 & 8.15 & 8.20 \\
\hline Total N & $\mathrm{ma} \mathrm{kq}^{-1}$ & 48.5 & - & - \\
\hline Soluble P (Olsen) & $\mathrm{mg} \mathrm{kq}^{-1}$ & 18.6 & - & - \\
\hline Water-soluble K & meq kg-1 & 1.19 & - & - \\
\hline heavy metals & $\mathrm{mg} \mathrm{kg}^{-1}$ & Avallable & lotal & lotal \\
\hline Nickel (Ni) & $\mathrm{mg} \mathrm{kg}^{-1}$ & 0.18 & 0.28 & 0.27 \\
\hline Cadmium (Cd) & $\mathrm{mg} \mathrm{kg}^{-1}$ & 0.02 & 0.15 & 0.17 \\
\hline Lead (Pb) & & 0.16 & 0.34 & 0.36 \\
\hline
\end{tabular}

*Olsen et al., 1954

For analysis of available heavy metals in soil, air-dried soils were extracted by a mixture containing $0.05 \mathrm{~mol} \mathrm{~L}^{-1}$ ethylene-diamine-tetra-acetic acid disodium (EDTA-Na2), $0.01 \mathrm{~mol} \mathrm{~L}^{-1} \mathrm{CaCl}_{2}$ and $0.1 \mathrm{~mol} \mathrm{~L}^{-1}$ Triethanolamine (TEA) (soil mixture ratio $1: 2$ at $\mathrm{pH} 1 / 47.0$ ). Briefly, $20 \mathrm{ml}$ of the EDTA solution (the EDTA $\mathrm{CaCl}_{2}$ - TEA mixture) was added to $10 \mathrm{~g}$ of soil sample placed in polypropylene tubes. The tubes were shaken on a rotating shaker for $3 \mathrm{~h}$ and then centrifuged (Page et al., 1982). Metals contents in the supernatant liquid were measured with a flame atomic absorption spectrometry (FAAS). The same procedure without samples (blank) was used as control. For analysis of heavy metals in rice straw and grains, $1 \mathrm{~g}$ of milled dry sample was extracted by digestion with nitric acid $\left(\mathrm{HNO}_{3}\right), 10 \mathrm{ml}$ for $3 \mathrm{~h}$ and then filtered $(45 \mathrm{~mm})$. Contents of heavy metals were determined by FAAS. The same procedure without samples was used as blank. Three replications were conducted for each sample.

\section{Statistical analysis}

Data were statistically analyzed according to ANOVA test and treatment means were compared using least significant difference (LSD) using a statistical analysis by IrriStat program and the nitrogen forms and their levels were compared for heavy metals concentration in straw, grain and soil using the least significant difference (LSD) test at $5 \%$ level of significance.

\section{RESULTS AND DISCUSSION}

\section{Effect of $\mathbf{N}$ forms and their levels on $\mathrm{Ni}, \mathrm{Cd}$ and $\mathrm{Pb}$ in soil}

Data in Table 2 showed that the various tested nitrogen forms and levels significantly influenced the concentration of the three tested heavy 
metals in the soil in both seasons. The application of nitrogen in the form of ammonium nitrate $\mathrm{NO}_{3} \mathrm{NH}_{4}$ gave the highest values of heavy metals in the soil in both seasons without any significant differences with those produced by urea nitrogen form. On the other hand nitrogen application in the form of ammonium sulfate in the terms of $\mathrm{NH}_{4} \mathrm{SO}_{3}$ significantly gave the lowest values of heavy metals in the soil in both seasons. Unfertilized treatment by $\mathrm{N}$ significantly reduced $\mathrm{NI}, \mathrm{Cd}$ and $\mathrm{Pb}$ concentrations in soil in the both seasons. It is hold true with the three studied heavy metals.

The interaction (Figure 1) between nitrogen forms and nitrogen levels had significant effect on the kinetics of the studied heavy metals in the soil. It was observed that increasing nitrogen level up to $219 \mathrm{~kg} \mathrm{~N}^{-1}$ use ammonium sulfate as nitrogen source significantly reduced the concentrations of the three tested heavy metals. On the other hand, increasing nitrogen levels beyond the level of $109 \mathrm{~kg} \mathrm{~N}^{-1}$ significantly increased the heavy metals concentrations in the soil solution at the case of both ammonium nitrate and Urea at the level of $219 \mathrm{~kg} \mathrm{~N} \mathrm{ha}^{-1}$. Since, Egyptian soil tend to be alkaline soil, the application of $\left(\mathrm{NH}_{4}\right)_{2} \mathrm{SO}_{4}$ might improve the chemical and physical properties as well as their drainage (Zayed et al., 2011). At the same time, ammonium sulfate increases the solubility of some heavy metals which will leach or move to drain well and quickly under rice submergence due to conversion of sulfate. One other possibility, increasing nitrogen rate at the case of ammonium sulfate will increase the sulfur concentration which will complex the heavy metals and deposited them and reduced their availability in the soil as a result of sedimentation. It is worthy to mention that the concentrations of the three heavy metals in the soil are less the permissible limits of WHO/FAO. The current findings are in a good accordance with those reported by Makino (2007) and Orathai et al. (2010).

Table 2: Concentration of $\mathrm{Ni}, \mathrm{Cd}$ and $\mathrm{Pb} \mathrm{mg} \mathrm{kg}{ }^{-1}$ dry soil as affected by $\mathrm{N}$ forms and levels.

\begin{tabular}{|c|c|c|c|c|c|c|}
\hline \multirow{3}{*}{$\mathrm{N}$ forms } & \multicolumn{2}{|c|}{$\mathrm{Ni}$} & \multicolumn{2}{|c|}{ Cd } & \multicolumn{2}{|c|}{$\mathbf{P b}$} \\
\hline & \multicolumn{6}{|c|}{$\mathrm{mg} \mathrm{kg}^{-1}$} \\
\hline & 2010 & 2011 & 2010 & 2011 & 2010 & 2011 \\
\hline Urea & $3.12 \mathrm{a}$ & $3.15 \mathrm{ab}$ & $0.199 a$ & $0.210 a$ & $4.23 \mathrm{a}$ & $4.20 \mathrm{a}$ \\
\hline $\mathrm{NH}_{4} \mathrm{No}_{3}$ & $3.17 \mathrm{a}$ & $3.23 \mathrm{a}$ & $0.202 a$ & $0.213 a$ & $4.21 \mathrm{a}$ & $4.13 \mathrm{a}$ \\
\hline$\left(\mathrm{NH}_{4}\right)_{2} \mathrm{SO}_{4}$ & $2.85 \mathrm{~b}$ & $3.09 \mathrm{~b}$ & $0.185 b$ & $0.179 \mathrm{~b}$ & $4.09 \mathrm{~b}$ & $3.96 \mathrm{~b}$ \\
\hline F Test & $\star \star$ & $*$ & * & * & * & * \\
\hline LSD (0.05) & 0.178 & 0.070 & 0.013 & 0.015 & 0.104 & 0.108 \\
\hline \multicolumn{7}{|l|}{$\mathrm{N}$ levels $\mathrm{kg} \mathrm{ha}^{-1}$} \\
\hline 0 & $3.22 \mathrm{a}$ & $3.34 \mathrm{a}$ & $0.213 a$ & $0.208 a$ & $5.32 \mathrm{a}$ & $5.34 \mathrm{a}$ \\
\hline 109 & $3.15 \mathrm{a}$ & $3.12 \mathrm{~b}$ & $0.178 b$ & $0.190 \mathrm{~b}$ & $4.16 \mathrm{~b}$ & $4.17 \mathrm{~b}$ \\
\hline 146 & $2.94 \mathrm{~b}$ & $3.09 \mathrm{~b}$ & $0.192 b$ & $0.198 a b$ & $4.00 \mathrm{c}$ & $3.75 \mathrm{c}$ \\
\hline 219 & $2.89 \mathrm{~b}$ & $3.07 \mathrm{~b}$ & $0.187 b$ & $0.193 a b$ & $3.23 \mathrm{~d}$ & $3.13 \mathrm{~d}$ \\
\hline F Test & $\star *$ & $\star \star$ & $*$ & $\star *$ & $\star \star$ & $\star \star *$ \\
\hline LSD (0.05) & 0.109 & 0.087 & 0.015 & 0.016 & 0.089 & 0.192 \\
\hline Interaction & ** & ** & ** & $*$ & $\star *$ & $\star *$ \\
\hline
\end{tabular}


Effect of $\mathbf{N}$ forms and levels on $\mathrm{Ni}, \mathrm{Cd}$ and $\mathrm{Pb}$ in straw and grain of rice

Data presented in Tables 3 and 4 revealed that the favorable effect of using different $\mathrm{N}$ forms in minimizing heavy metals in the soil significantly reflected on heavy metals concentration on rice grain and straw (Table 3). Interestingly, the tested nitrogen forms significantly affected the concentrations of heavy metals in rice straw in both seasons. Especially ammonium sulfate form which gave the lowest values in tested heavy metals in grain and straw of rice.

Regarding $\mathrm{Ni}$ concentration in rice straw urea application had significant ability to reduce $\mathrm{Ni}$ concentration in rice grain and straw whereas; it occupied the second rank after ammonium sulfate in this concern. The effect of urea nitrogen source in Ni concentration was not coincided with that happened in rice straw. This contradictory effect might be due to the role of $\mathrm{Ni}$ element in urea metabolism inside the plant tissue as co-activator urease enzyme (Milton et al., 2009).

The favorable effect of $\mathrm{NH}_{4}+$ in reducing heavy metals in rice straw contributed to its effect on their concentrations in soil as abovementioned. Other possibilities are; the antagonistic effect between $\mathrm{NH}_{4}{ }^{+}$and some heavy metals such as $\mathrm{Cd}$ which was reduced its uptake, dilution effect and ammonium ions cause cell membrane potential depolarization, which results in the influx of $\mathrm{NH}_{4}{ }^{+}$into the cytoplasm of the root cells reducing $\mathrm{Cd}$ uptake (Zaccheo et al., 2006). Ammonium nitrate gave the highest values of all studied heavy metals in both seasons. Both Urea and ammonium sulfate were at the same level of significance in both seasons regarding the concentration of $\mathrm{Cd}$ and $\mathrm{Pb}$ in rice straw and that was corresponding with their effect in soil. The obtained results are in a good harmony with those reported by Milton et al. (2009), Jalloh et al. (2009) and Xie et al. (2009). On the other hand, the abovementioned results were in a contrast with those reported by (Nadeem et al., 2010).

Regarding the effect of nitrogen levels, data in table 3 revealed that significant effects was given by the nitrogen levels on the concentration of the three heavy metals in rice straw in both seasons. The nitrogen level up to the higher studied one i.e. $219 \mathrm{~kg} \mathrm{~N}^{-1}$ significantly reduced the concentration of $\mathrm{Ni}$ and $\mathrm{Pb}$ in e rice straw in both seasons which gave the lowest values. Regarding $\mathrm{Cd}$, increasing level beyond $109 \mathrm{~kg} \mathrm{~N} \mathrm{ha}^{-1}$ didn't exert significant reduction in $\mathrm{Cd}$ concentration in rice straw. Minimizing the heavy metals by increasing nitrogen level might be attributed to the dilution effect and increasing biomass production.

It was observed that the straw content of heavy metals were higher than those obtained in unpolished rice grain in both seasons under nitrogen forms and levelsand that was clearly with using ammonium sulfate. Haytham et at. (2004) and Hammad et al.( 2011) found that heavy metals content in unpolished rice is less than those obtained by rice straw. It is mentioning here the concentration of the studied heavy metals in either straw or grain of rice is less the permissible limits according to WHO/FAO. 

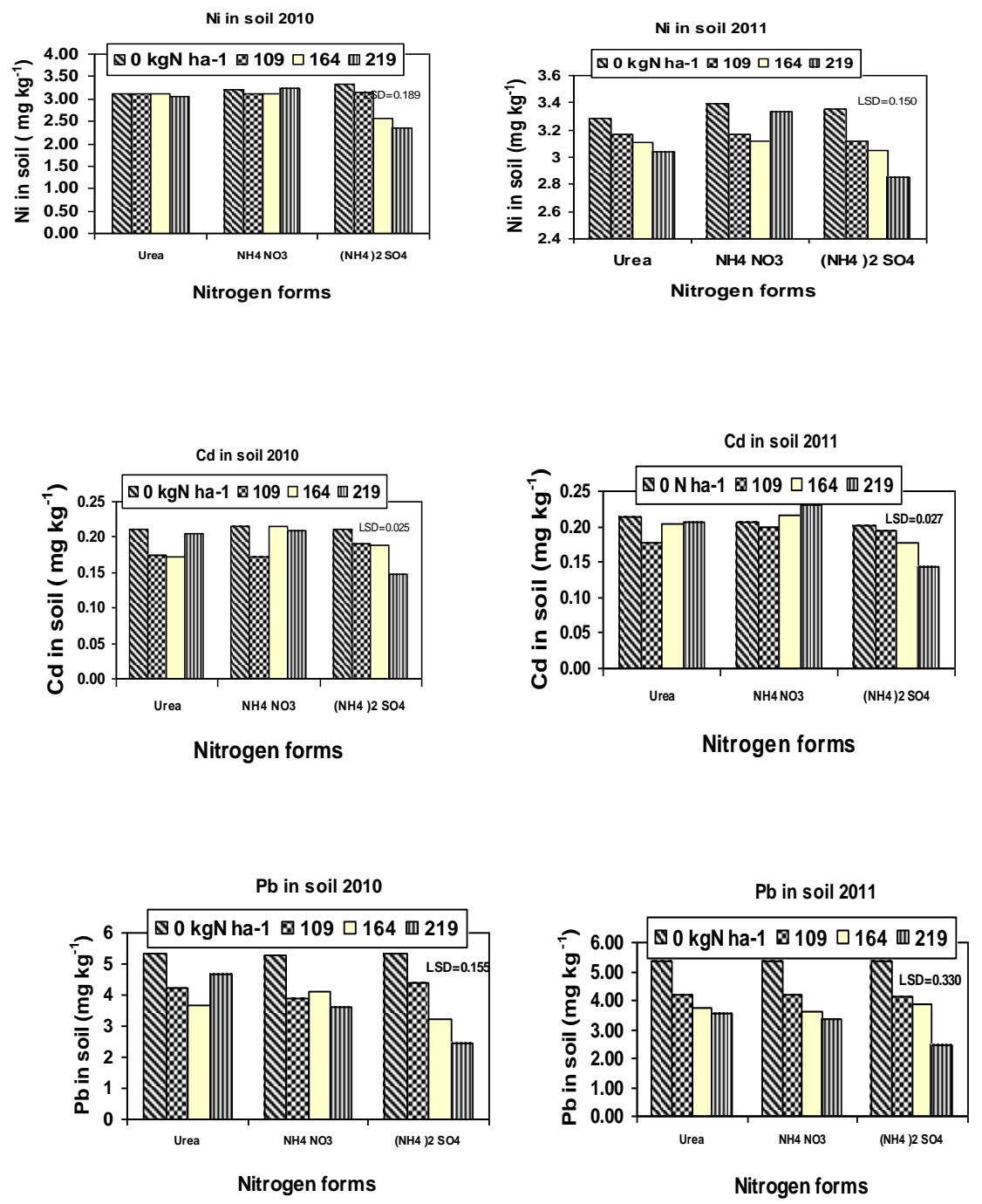

Figure (1): Availability of $\mathrm{Ni}, \mathrm{Cd}$ and $\mathrm{Pb} \mathrm{mg} \mathrm{kg} \mathrm{in}^{-1}$ soil as affected by the interaction between $\mathbf{N}$ forms and their levels during 2010 and 2011 seasons.

This finding are in a good conformity with those reported by Pankovic et al.(2000) and Wangstrand et al.(2007) and in a contrasting with Hammad et al.(2011) which reported increasing heavy metals in all rice organs with increasing urea rate and farm yard manure rate. With respect to the interaction effect ( figures $2 \& 3$ ), the interaction between nitrogen forms and level had significant effect on the concentrations of heavy metals in either 
grain and straw yield in both seasons. From data related to the interaction, it ca be concluded that the heavy metals continue to decrease as nitrogen level progressively increased up to $219 \mathrm{~kg} \mathrm{~N}^{-1}$ when ammonium sulfate was used as nitrogen forms. Increasing nitrogen level beyond $109 \mathrm{~kg} \mathrm{~N}^{-1}$ increased the heavy metals content in rice straw and grain respectively when ammonium nitrate was used as nitrogen source. Regarding the response of heavy metals to nitrogen level, it was found that the nitrogen at the rate of $109 \mathrm{~kg} \mathrm{~N} \mathrm{ha}^{-1}$ using urea form succeeded to reduce the concentration of $\mathrm{Ni}$ and $\mathrm{Cd}$ in rice grain and straw in both seasons. In continuously, the increasing urea application up to $219 \mathrm{~kg} \mathrm{~N}^{-1}$ significantly diminished the concentration of $\mathrm{Pb}$ in rice straw and grain in both seasons.

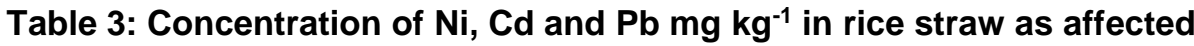
by $\mathrm{N}$ forms and their levels during 2010 and 2011 seasons.

\begin{tabular}{|c|c|c|c|c|c|c|}
\hline \multirow{3}{*}{$\mathrm{N}$ forms } & \multicolumn{2}{|c|}{$\mathrm{Ni}$} & \multicolumn{2}{|c|}{ Cd } & \multicolumn{2}{|c|}{$\mathrm{Pb}$} \\
\hline & \multicolumn{6}{|c|}{$\mathrm{mg} \mathrm{kg}^{-1}$} \\
\hline & 2010 & 2011 & 2010 & 2010 & 2011 & 2010 \\
\hline Urea & $9.97 b$ & $10.31 b$ & $0.395 \mathrm{~b}$ & $0.400 \mathrm{~b}$ & $10.31 b$ & $9.97 \mathrm{~b}$ \\
\hline $\mathrm{NH}_{4} \mathrm{No}_{3}$ & $10.88 a$ & $11.59 a$ & $0.437 \mathrm{a}$ & $0.440 \mathrm{a}$ & $11.59 \mathrm{a}$ & $10.88 a$ \\
\hline$\left(\mathrm{NH}_{4}\right)_{2} \mathrm{SO}_{4}$ & $9.88 \mathrm{~b}$ & $10.21 b$ & $0.376 \mathrm{~b}$ & $0.390 \mathrm{~b}$ & $10.21 b$ & $9.88 \mathrm{~b}$ \\
\hline F Test & $\star *$ & ** & $* *$ & $* *$ & $* *$ & $* *$ \\
\hline LSD (0.05) & 0.500 & 0.610 & 0.006 & 0.500 & 0.006 & 0.500 \\
\hline \multicolumn{7}{|l|}{ N levels kg ha ${ }^{-1}$} \\
\hline 0 & $10.7 \mathrm{a}$ & $11.52 \mathrm{a}$ & $0.440 \mathrm{a}$ & $0.440 \mathrm{a}$ & $11.52 \mathrm{a}$ & $10.70 a$ \\
\hline 109 & $10.6 \mathrm{a}$ & $11.04 b$ & $0.410 \mathrm{~b}$ & $0.410 \mathrm{~b}$ & $11.04 b$ & $10.60 \mathrm{a}$ \\
\hline 146 & $10.11 b$ & $10.45 \mathrm{c}$ & $0.401 \mathrm{~b}$ & $0.400 \mathrm{~b}$ & $10.45 c$ & $10.11 \mathrm{~b} \mathrm{~b}$ \\
\hline 219 & $9.46 \mathrm{c}$ & $9.75 d$ & $0.400 \mathrm{~b}$ & $0.390 \mathrm{~b}$ & $9.75 d$ & $9.46 c b$ \\
\hline F Test & ** & ** & $* *$ & ** & ${ }^{* *}$ & $* *$ \\
\hline LSD (0.05) & 0.470 & 0.430 & 0.005 & 0.005 & 0.430 & 0.470 \\
\hline Interaction & ** & ** & $\star *$ & ** & ** & ** \\
\hline
\end{tabular}

Table 4: Concentration of $\mathrm{Ni}, \mathrm{Cd}$ and $\mathrm{Pb} \mathrm{mg} \mathrm{kg} \mathrm{in}^{-1}$ ice grain as affected by $\mathrm{N}$ forms and their levels during 2010 and 2011 seasons.

\begin{tabular}{|c|c|c|c|c|c|c|}
\hline \multirow{3}{*}{$\mathbf{N}$ forms } & \multicolumn{2}{|c|}{$\mathrm{Ni}$} & \multicolumn{2}{|c|}{ Cd } & \multicolumn{2}{|c|}{$\mathbf{P b}$} \\
\hline & \multicolumn{6}{|c|}{$\mathrm{mg} \mathrm{kg}^{-1}$} \\
\hline & 2010 & 2011 & 2010 & 2011 & 2010 & 2011 \\
\hline Urea & $2.975 a b$ & $2.974 \mathrm{a}$ & $0.234 \mathrm{a}$ & $0.250 \mathrm{a}$ & $2.682 \mathrm{a}$ & $2.726 \mathrm{a}$ \\
\hline $\mathrm{NH}_{4} \mathrm{No}_{3}$ & $3.077 \mathrm{a}$ & $2.987 \mathrm{a}$ & $0.230 \mathrm{a}$ & $0.241 \mathrm{a}$ & $2.578 \mathrm{~b}$ & $2.644 \mathrm{~b}$ \\
\hline$\left(\mathrm{NH}_{4}\right)_{2} \mathrm{SO}_{4}$ & $2.899 \mathrm{~b}$ & $2.876 \mathrm{~b}$ & $0.197 \mathrm{~b}$ & $0.200 \mathrm{~b}$ & $2.542 \mathrm{~b}$ & $2.549 \mathrm{c}$ \\
\hline F Test & * & * & ** & ** & ** & ** \\
\hline LSD (0.05) & 0.121 & 0.090 & 0.007 & 0.006 & 0.037 & 0.054 \\
\hline \multicolumn{7}{|l|}{$\mathrm{N}$ levels kg ha ${ }^{-1}$} \\
\hline 0 & $3.226 \mathrm{a}$ & $3.238 \mathrm{a}$ & $0.248 \mathrm{a}$ & $0.270 \mathrm{a}$ & $2.852 \mathrm{a}$ & $2.843 \mathrm{a}$ \\
\hline 109 & $2.991 \mathrm{~b}$ & $2.697 \mathrm{c}$ & $0.230 \mathrm{ab}$ & $0.240 \mathrm{~b}$ & $2.689 \mathrm{~b}$ & $2.700 \mathrm{~b}$ \\
\hline 146 & $2.940 \mathrm{~b}$ & $2.915 \mathrm{~b}$ & $0.235 \mathrm{~b}$ & $0.240 \mathrm{~b}$ & $2.609 \mathrm{c}$ & $2.638 \mathrm{c}$ \\
\hline 219 & $2.778 \mathrm{c}$ & $2.932 \mathrm{~b}$ & $0.233 \mathrm{~b}$ & $0.237 \mathrm{~b}$ & $2.251 d$ & $2.378 \mathrm{~d}$ \\
\hline F Test & ** & ** & * & ** & ** & ** \\
\hline LSD (0.05) & 0.089 & 0.121 & 0.006 & 0.007 & 0.045 & 0.049 \\
\hline Interaction & ** & ** & $\star *$ & ** & ** & ** \\
\hline
\end{tabular}


Form going discussion, it could be concluded that the ammonium sulfate was more efficient than other two tested nitrogen forms in reducing the concentration of heavy metals either in soil or in rice grain even though with using higher nitrogen level of $219 \mathrm{~kg} \mathrm{~N}^{-1}{ }^{1}$. The form of ammonium sulfate gave the highest values of abovementioned traits, except number of unfilled grains without any significant differences with those produced by urea nitrogen form in one season of the two study seasons.

Ni in straw 2010

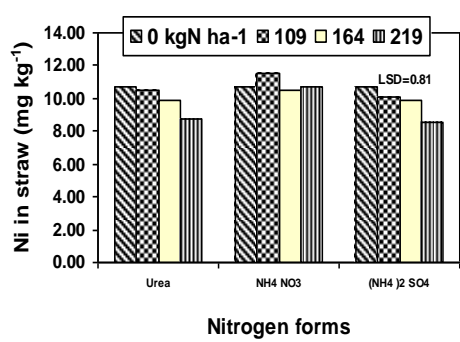

Cd in straw 2010

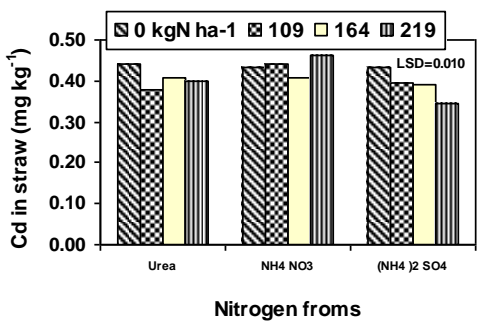

$\mathrm{Pb}$ in straw 2010

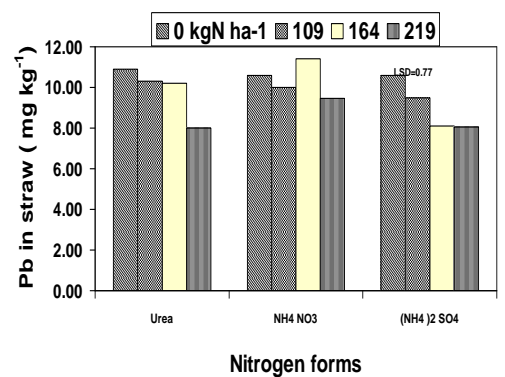

Ni in straw 2011

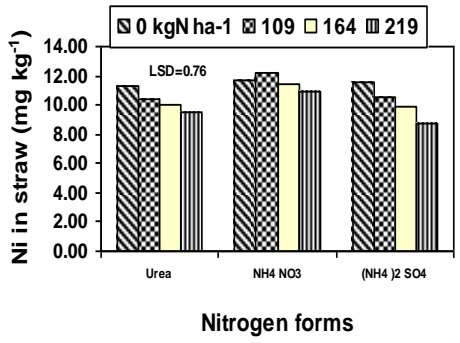

Cd in straw 2011

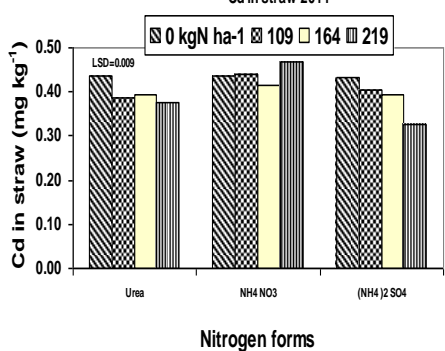

$\mathrm{Pb}$ in straw 2011

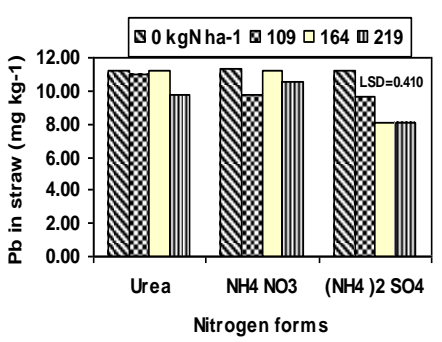

Figure 2: Concentrations of $\mathrm{Ni}, \mathrm{Cd}$ and $\mathrm{Pb} \mathrm{mg} \mathrm{kg}{ }^{-1}$ in straw as affected by the interaction between $\mathrm{N}$ forms and their levels during 2010 and 2011 seasons 
On the other hand, the form of ammonium nitrate gave the highest values of number of unfilled grains in both study seasons followed by urea form. By the way, the lowest values of yield and yield components were produced by ammonium nitrate in both seasons.

Under poor quality water in the terms of contamination one by heavy metals, ammonium sulfate had higher efficiency for protect plants from the harmful effect of heavy metals by increasing protective antioxidant (Jalloh et al. 2009), increasing nitrogen uptake and photosynthesis rate during vegetative growth and during grain filling period leading to improve of yield components resulted in higher grain yield followed by urea.

Table 5: Number of panicle hill-1, panicle length and panicle weight as affected by nitrogen forms and their levels during 2010 and 2011 seasons.

\begin{tabular}{|c|c|c|c|c|c|c|}
\hline \multirow{2}{*}{$\mathrm{N}$ forms } & \multicolumn{2}{|c|}{ No of panicle hill-1 } & \multicolumn{2}{|c|}{ Panicle length(cm) } & \multicolumn{2}{|c|}{ Panicle weight(g) } \\
\hline & 2010 & 2011 & 2010 & 2011 & 2010 & 2011 \\
\hline Urea & $16.89 \mathrm{~b}$ & $17.43 a$ & $19.06 \mathrm{~b}$ & $19.05 \mathrm{a}$ & $2.73 \mathrm{a}$ & $2.78 \mathrm{~b}$ \\
\hline $\mathrm{NH}_{4} \mathrm{No}_{3}$ & $13.54 \mathrm{c}$ & $14.24 b$ & $18.53 \mathrm{~b}$ & $18.03 \mathrm{~b}$ & $2.60 \mathrm{~b}$ & $2.57 \mathrm{c}$ \\
\hline$\left(\mathrm{NH}_{4}\right)_{2} \mathrm{SO}_{4}$ & $17.69 a$ & $17.80 a$ & $19.64 \mathrm{a}$ & $19.39 \mathrm{a}$ & $2.80 \mathrm{a}$ & $2.91 \mathrm{a}$ \\
\hline F Test & ** & ** & $\star \star$ & $\star \star *$ & $\star \star$ & $\star *$ \\
\hline LSD0.05 & 0.51 & 1.13 & 0.556 & 0.375 & 0.088 & 0.107 \\
\hline $\mathrm{N}$ levels $\mathrm{kg} \mathrm{ha}^{-1}$ & & & & & & \\
\hline 0 & $15.07 \mathrm{~d}$ & $15.13 \mathrm{c}$ & $17.85 \mathrm{~d}$ & $17.58 \mathrm{c}$ & $2.55 \mathrm{~d}$ & $2.32 \mathrm{c}$ \\
\hline 109 & $15.86 \mathrm{c}$ & $15.74 b c$ & $18.82 \mathrm{c}$ & $18.83 \mathrm{~b}$ & $2.60 \mathrm{c}$ & $2.64 \mathrm{~b}$ \\
\hline 146 & $16.51 \mathrm{~b}$ & 17.22ab & $19.48 \mathrm{~b}$ & $19.30 \mathrm{a}$ & $2.89 \mathrm{~b}$ & $2.98 \mathrm{a}$ \\
\hline 219 & $17.25 \mathrm{a}$ & $17.87 \mathrm{a}$ & $20.15 \mathrm{a}$ & $19.58 \mathrm{a}$ & $3.10 \mathrm{a}$ & $3.06 \mathrm{a}$ \\
\hline F Test & ** & ** & ** & $\star *$ & ** & ** \\
\hline LSD0.05 & 0.357 & 1.47 & 0.446 & 0.365 & 0.09 & 0.118 \\
\hline Interaction & ns & $\mathrm{ns}$ & ${ }^{* *}$ & ${ }^{* \star}$ & ${ }^{*}$ & ${ }^{* *}$ \\
\hline
\end{tabular}

Other possibilities that is the Egyptian soil tend to be alkaline as mentioned in table 1, the application of ammonium sulfate might be improved the physical and chemical soil properties resulted in improving rice growth and subsequently yield and yield components. On the other hand ammonium nitrate was less efficient that might be attributed to the higher nitrogen losses under submergence condition and its failure to reduce heavy metals uptake. Similar findings were reported by Zaccheo et al., 2006, Milton et al.(2009), Jalloh et al.(2009) and Xie et al.(2009). Regarding nitrogen levels impact, nitrogen fertilizer treatments had significant and positive impact on yield attributes in both seasons (Tables 5\&6). Increasing nitrogen level up to 219 $\mathrm{kg} \mathrm{N} \mathrm{ha-1}$ significantly increased panicle numbers hill-1, panicle length and weight, number of filled grains panicle ${ }^{-1}$ and grainy yield $t$ ha $^{-1}$ in both seasons without significant differences with those produced by $146 \mathrm{~kg} \mathrm{~N}^{-1}$ regarding number of panicle hill ${ }^{-1}$, panicle length and panicle weight in 2011, and filled grain per panicle and grain yield in both seasons. The tested higher nitrogen level of $219 \mathrm{~kg} \mathrm{~N}^{-1}$ gave the highest values of abovementioned traits in both study seasons. However, increasing nitrogen rates up to $219 \mathrm{~kg}$ $\mathrm{N}$ ha ${ }^{-1}$ pronounced reduced number of unfilled grains per panicle. 

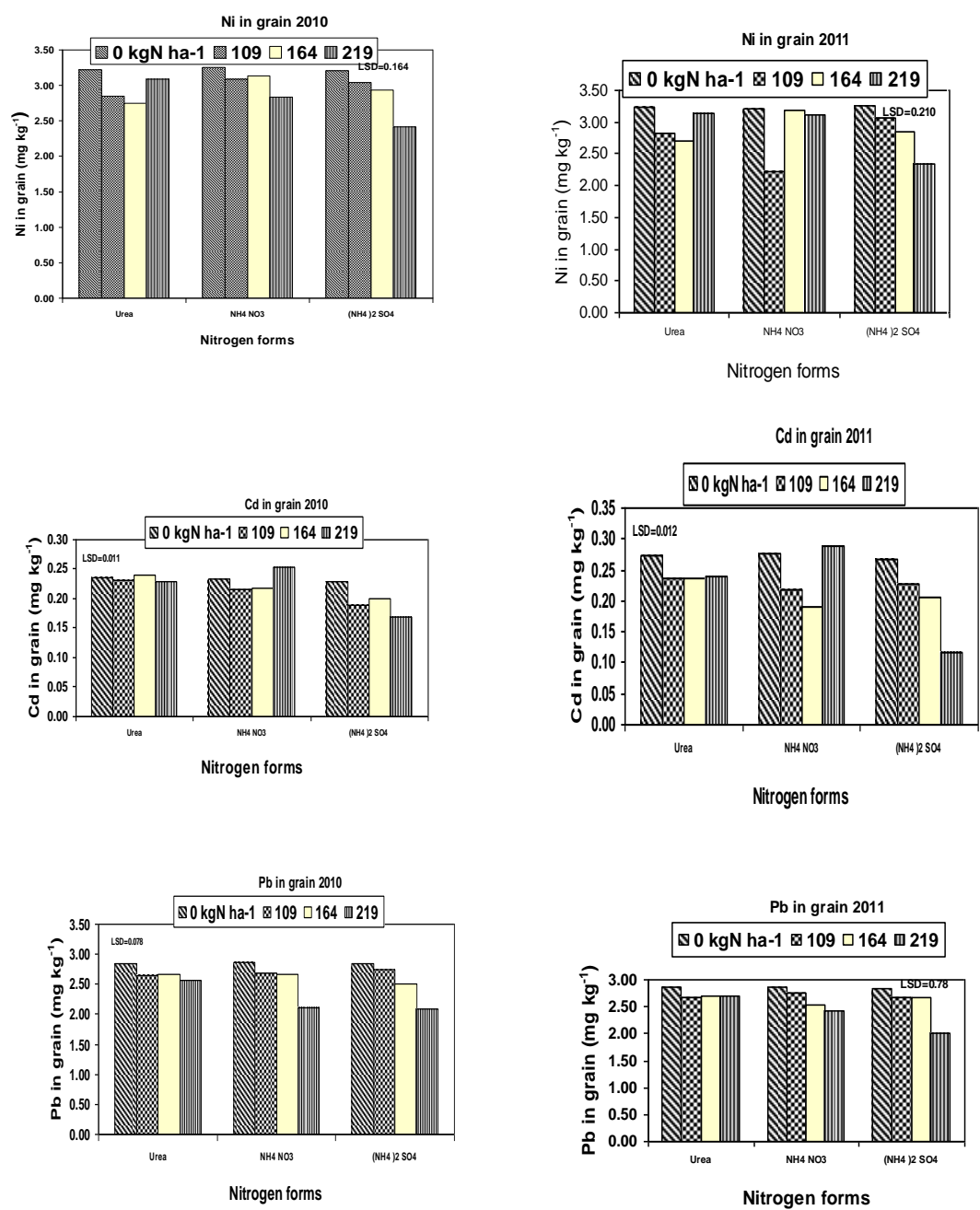

Figure 3. Concentrations of $\mathrm{Ni}, \mathrm{Cd}$ and $\mathrm{Pb} \mathrm{mg} \mathrm{kg}$ in $^{-1}$ grain as affected by the interaction between $\mathrm{N}$ forms and their levels during 2010 and 2011 seasons

The treatment without nitrogen application gave the lowest values of yield attributes, except unfilled grains where it gave the maximum value of it. The obtained improvement in yield attributes to the increase in the accumulation of photosynthesis from source to sink especially during grain filling as well as delaying leaf senescence. That might be also due to stimulate the vigorous growth superficial roots, increased the synthesis of 
cytokinins ( mainly Zeatian ) in roots, and delayed the appearance of the absesic acid (ABA) peak in both leaves and filling grains . High ratio of Zeatian /ABA enhanced the synthesis of RNA ,which resulted in protein synthesis for carbon assimilation and transportation (Yang and Sun, 1992) .The present findings are in good accordance with the results of Meena et al. (2003) ,Shivay and Singh .(2003), Gautam .(2004) and Zayed et al .(2005) as well as Zayed el al.(2006). With respect to the interaction effect, the interaction ( figures 4and 5) between nitrogen forms and nitrogen levels had significant effect on panicle length, panicle weight, number of filled grain, number of unfilled grains panicle ${ }^{-1}$ and rice grain yield in both seasons. The results of interaction came to confirm the superiority of ammonium sulfate to higher nitrogen level of $219 \mathrm{~kg} \mathrm{~N}^{-1}$. The latter combination gave the maximum values of abovementioned traits in both seasons. Also the results confirmed the inferiority of ammonium nitrate. At the same time, the results of interaction showed that the rice plants significantly responded to nitrogen level up to only $146 \mathrm{~kg} \mathrm{~N} \mathrm{ha}^{-1}$ with using Urea as nitrogen form.

Table 6: Number of filled grains panicle ${ }^{-1}$, number of unfilled grains panicle $e^{-1}$ and grain yield $t$ ha $^{-1}$ as affected by nitrogen forms and their levels during 2010 and 2011 seasons.

\begin{tabular}{|c|c|c|c|c|c|c|}
\hline \multirow[t]{2}{*}{$\mathrm{N}$ forms } & \multicolumn{2}{|c|}{$\begin{array}{l}\text { No of filled grains } \\
\text { panicle }{ }^{-1}\end{array}$} & \multicolumn{2}{|c|}{$\begin{array}{l}\text { No of unfilled grains } \\
\text { panicle }^{-1}\end{array}$} & \multicolumn{2}{|c|}{ Grain yield $t$ ha $^{-1}$} \\
\hline & 2010 & 2011 & 2010 & 2011 & 2010 & 2011 \\
\hline Urea & $123.9 \mathrm{~b}$ & $122.9 a$ & $13.66 c$ & $18.75 a$ & $7.95 a$ & $8.20 b$ \\
\hline $\mathrm{NH}_{4} \mathrm{No}_{3}$ & $118.2 \mathrm{c}$ & $117.9 \mathrm{~b}$ & $18.63 a$ & $19.75 a$ & $6.69 \mathrm{~b}$ & $7.20 c$ \\
\hline$\left(\mathrm{NH}_{4}\right)_{2} \mathrm{SO}_{4}$ & $127.8 \mathrm{a}$ & $125.9 a$ & $15.29 \mathrm{~b}$ & $15.56 \mathrm{~b}$ & $8.19 a$ & $8.60 a$ \\
\hline F Test & $\star *$ & $\star \star$ & ** & $\star *$ & $\star \star *$ & $\star *$ \\
\hline LSD (0.05) & 2.25 & 3.08 & 1.36 & 1.01 & 0.76 & 0.325 \\
\hline \multicolumn{7}{|l|}{$\mathrm{N}$ levels $\mathrm{kg} \mathrm{ha}^{-1}$} \\
\hline 0 & $109.8 c$ & $108.5 c$ & $25.00 \mathrm{a}$ & $25.92 a$ & $5.57 c$ & $6.05 c$ \\
\hline 109 & $121.2 b$ & $119.8 b$ & $16.93 b$ & $19.08 b$ & $7.58 b$ & $7.80 \mathrm{~b}$ \\
\hline 146 & $131.0 a$ & $129.8 a$ & $11.58 \mathrm{c}$ & $15.17 \mathrm{c}$ & $8.80 a$ & $9.00 \mathrm{a}$ \\
\hline 219 & $131.3 a$ & $130.8 \mathrm{a}$ & $9.92 c$ & $11.92 \mathrm{~d}$ & $8.50 a$ & $9.15 a$ \\
\hline F Test & $\star \star$ & $\star *$ & $\star *$ & $\star *$ & $\star \star *$ & $\star *$ \\
\hline LSD (0.05) & 3.33 & 2.85 & 1.76 & 1.11 & 0.805 & 0.38 \\
\hline Interaction & $\star *$ & $\star *$ & * & $\star * *$ & $\star \star *$ & $* *$ \\
\hline
\end{tabular}



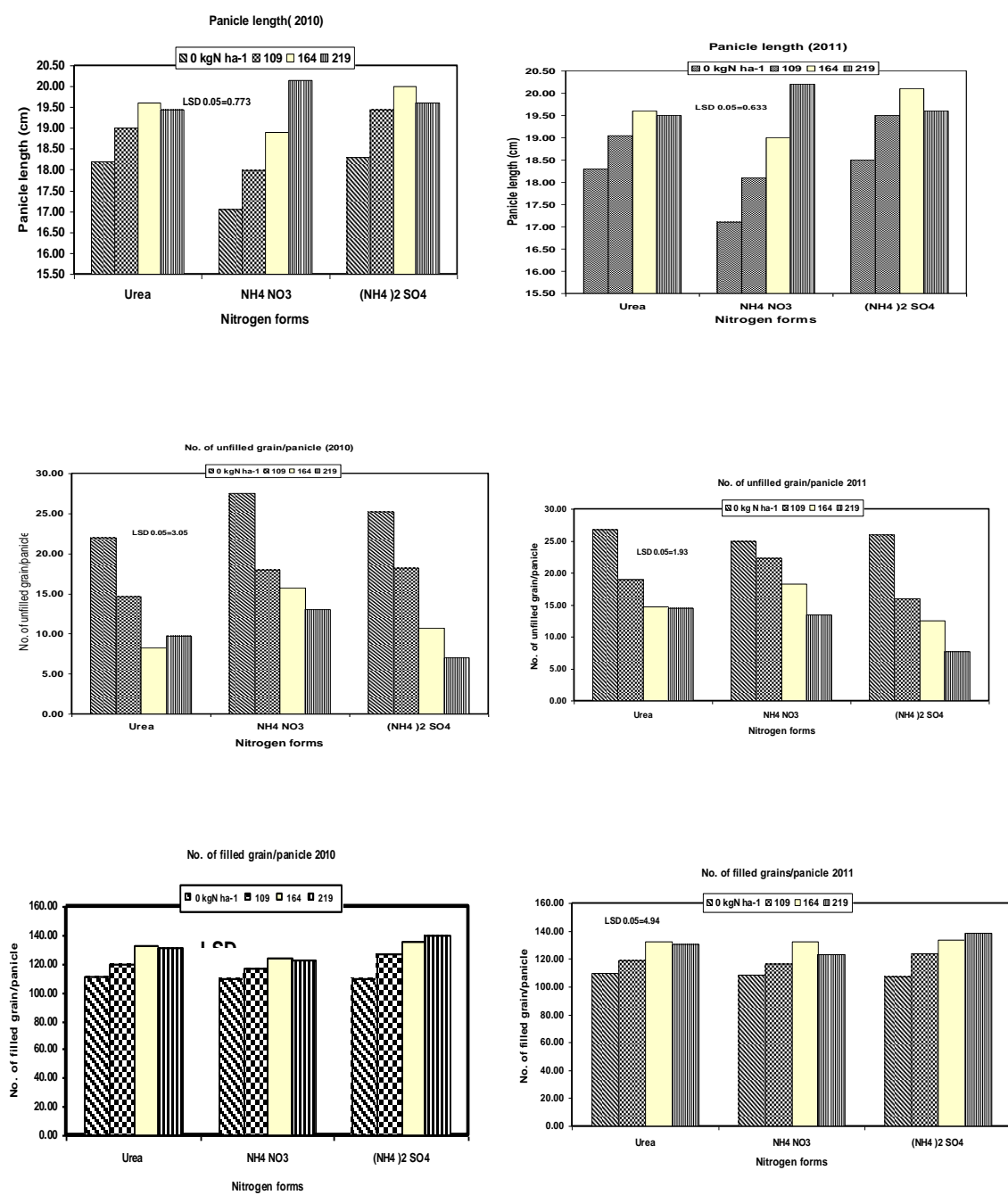

Figure 4: Panicle length, number of filled grains panicle ${ }^{-1}$, and number of unfilled grains panicle ${ }^{-1}$ of rice as affected by the interaction between $\mathbf{N}$ forms and their levels. 

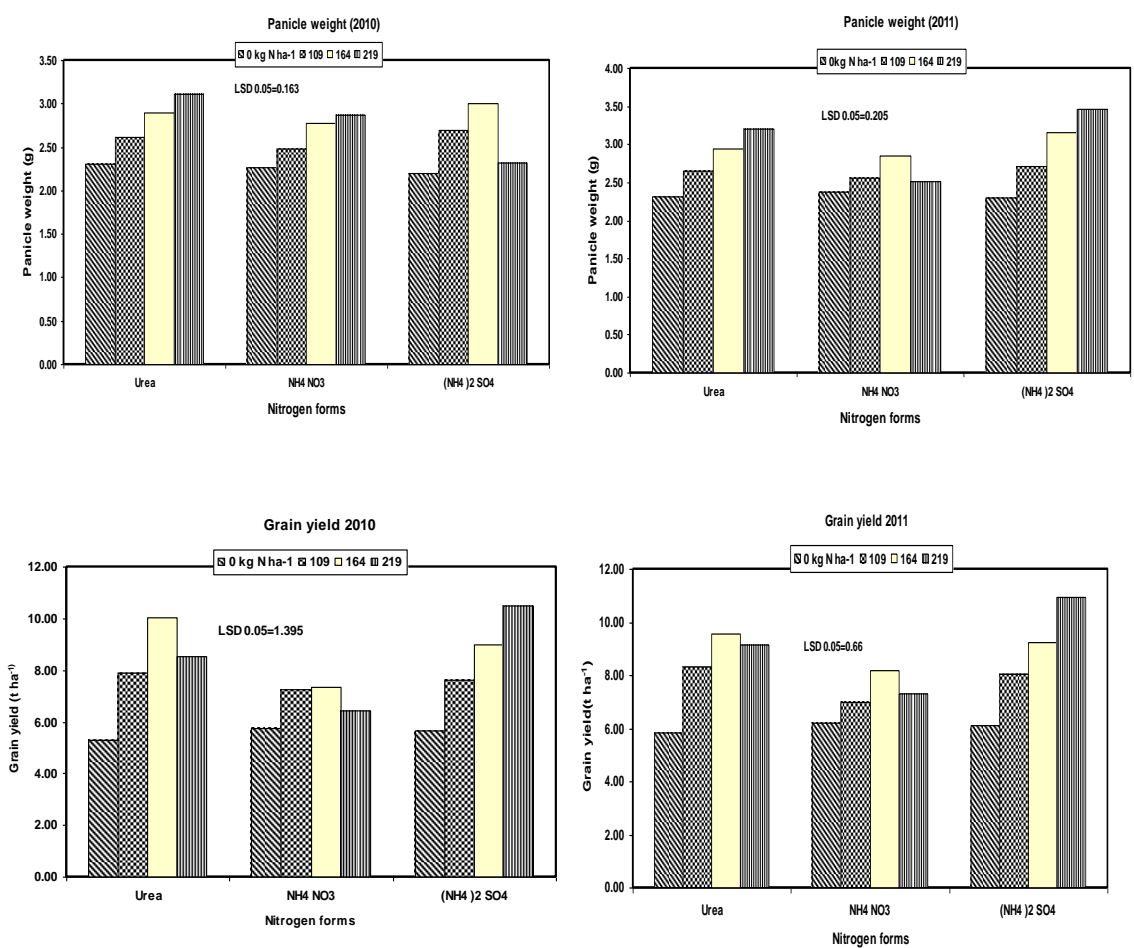

Figure 5: Panicle weight and grain yield of rice as affected by the interaction between $\mathbf{N}$ forms and their levels

\section{REFERENCES}

Allison, L.E, (1965). Organic carbon, in Methods of Soil Analysis. pp 1378. American Society of Agronomy.

Bremmer, J.M. and C.S. Mulvaney. (1982). Nitrogen-total. In: Methods of Soil Analysis, Page, A.L.; R.H. Miller and D.R. Keeney (Eds.). ASA and SSSA, Madison, WI., USA., 595-624.

Frechilla S. EM. Bonzalez; M. Royuela; C. Arrese-Igor; C. Lamsfus and PM. Aparicio-Tejo (1999) Source of nitrogen nutrition affects pea growth involving changes in stomatal conductance and photorespiration. $J$ Plant Nutr., 22:911-926.

Gautam ,A.K. (2004). Effect of nitrogen level and spacing on productivity and quality of inbred and hybrid aromatic rice .PhD. thesis , Division of Agronomy. ,Indian Agrric., Res. Instit. , New Delhi, India. 
Hammad, S. A. ; E.S. Naeem and Howida B. El-habet (2011). Concentrations of Nickel, Lead and Cadium in rice plants as affected by farm yard manure. J. Soil Sci. and Agric. Eng., Mansoura Univ., Vol. $2(2): 171-182$.

Haytham, M. E. M. Irshad; A. M El-Serfy; T. Honna A.K.S; Hassan; T. Mohamed; S. Yamamoto and A. Zahoor. (2004). Effect of water quality on grain yield and nutrient uptake of rice (Oryza sativa L.). Acta Agronomica Hungarica, 52(2):141 - 148

Jalloh M.A.; J. Chen; F. Zhen and G. Zhang, (2009). Effect of different N fertilizer forms on anti-oxidant capacity and grain yield of rice growing under Cd stress. J Hazard Mater, 162:1081-1085.

Jansson G. and I.Oborn, (2000). Cadmium in Swedish carrots and the influence of soil factors. Acta Agric Scand Sect B Soil Plant 50:49-56.

Klute, A, (1986). Water retention: Laboratory methods. In Methods of Soil Analysis, Part 1. 2nd Ed. A. Klute (ed.) Agron. Monogr. No.9. ASA, Madison WI, pp.653-661.

Landberg T. and M. Greger, (2003). Influence of N and N Supplementation on Cd Accumulation in Wheat Grain, in 7th International Conference on the Biogeochemistry of Trace Elements, Uppsala '03, Conference Proceedings 1: III, Sweedish University of Agricultural Sciences, Uppsala, Sweden, 90-91.

Lindsay, W. L. and W. A. Norvell, (1978). Development of a DTPA soil test for zinc, iron, manganese, and copper. Soil Sci. Soc. Amer. J. 42:421-428.

Loosemore N. Straczek A. Hinsinger P and Jaillard B, (2004). Zinc mobilisation from a contaminated soil by three genotypes of tobacco as affected by soil and rhizosphere pH. Plant Soil,260:19-32.

Makino, T.m, (2007). Heavy metals pollution of soil and a new approach to its remediation: research experiences in Japan. In 'Proceedings of the International Workshop of ESAFS8: New Solutions to Soil Pollution and Distribution, Bioavailability and Management of Heavy Metals'. (Ed ZS Chen) pp. 55-74 (Food and Fertilizer Technology Center for the Asian and Pacific Region: Taipei, Taiwan).

Meena, S.L.; S.Singh, and Y.S. Shivay, (2003). Response of hybrid rice (oryza sativa) to nitrogen and potassium application in sandy clay-loam soils. Indian J. Agric. Sci: 73(1): 8-11.

Milton F. M. A.R. Reis; L. A. C. Moraes; J. L. Junior; R. Vivian; C. P. Cabral and E. Malavolta, (2009). Effects of Molybdenum, Nickel, and Nitrogen Forms on the Mineral Nutrition and Growth of Rice Plants. Communications in Soil Science and Plant AnalysisVolume 40, Issue 21-22, December, pp. 3238-3251.

Muhammad J. H.; F.Wang; S. Ali and G. Zhang, (2005). Toxic effect of cadmium on rice as affected by nitrogen fertilizer form. Plant and soil, 277:359-365

Nadeem S. S. S Saifullah; M. H. Malhi; A. Zia; S.Naeem and G. Farid, (2010). Role of mineral nutrition in minimizing cadmium accumulation by plants. J Sci Food Agric 90: 925-937. 
Oborn I; G. Jansson and L. Johnsson, (1995). A field study on the influence of soil $\mathrm{pH}$ on trace element levels in spring wheat, potatoes and carrots. Water Air Soil Pollut. 85:835-840.

Olsen S. C. Cole; F. Watanabe and L. Dean, (1954). Estimation of available phosphorus in soils by extraction withsodium bicarbonate. USDA Circular Nr 939, US Gov. Print. Office, Washington, D.C.

Orathai S. L.SrisawatA; O. Chomsiriand N. Notesiri, (2010). Soil management for reduce $\mathrm{Cd}$ concentration in rice grains. 19th World Congress of Soil Science, Soil Solutions for a Changing World,1 - 6 August, Brisbane, Australia, 52-54.

Page, A.L. R.H. Miller and D.R. Keeney, (1982). Methods of Soil Analysis. 2nd Edn., Amercen Society of Agronomy, Madison, WI., USA.

Pankovic D. M. Plesnicar; I.A. Maksimoviic; N. Petrovic; Z. Sakac and R. Kastori, (2000). Effect of nitrogen nutrition on photosynthesis in $\mathrm{Cd}$ treated sunflower plants. Ann Bot 86:841-847.

Richards L. A. (Ed.) 1954. Diagnosis and Improvement of Saline and Alkali Soils. USDA Agriculture Handbook 60, Washington D. C.

Shivay Y.S.and S.Singh, (2003). Effect of planting geometry and nitrogen level on growth ,yield and nitrogen -use efficiency of scented hybrid rice(Oryza sativa). Indian Journal of Agronomy, 48(1):42-44.

Wang C.X.; Z. Mo; H. Wang; Z.J. Wang; Z. H.Cao, (2003). The transportation, time-dependent distribution of heavy metals in paddy crops. Chemosphere, 50(6):717-723.

Wangstrand H. J. Eriksso and I. Oborn, (2007). Cadmium concentration in winter wheat affected by nitrogen fertilization. Eur J Agron., 26:209214.

Xie H.L. R.F. Jiang; F.S. Zhang; S.P. McGrath and F.J. Zhao, (2009). Effect of nitrogen form on the rhizosphere dynamics and uptake of cadmium and zinc by the hyper accumulator Thlaspi caerulescens. Plant Soil 318:205-215.

Yang ,X. and X.Sun, (1992). Physiological mechanism of varietal differences in rice plant response to low N level .Acta Pedol.sin.,29:73-79.

Zaccheo P; C. Laura and D.M.P. Valeria, (2006). Ammonium nutrition as a strategy for cadmium metabolisation in the rhizosphere of sunflower. Plant Soil 283:43-56).

Zayed ,B.A.; El-Refaee I.S.; Gorgy R.N. and A. A. M. Abd El -Rahman, (2005). Effect of sowing dates, plant spacing and nitrogen levels on growth and yield of rice under saline soil .The $11^{\text {th }}$ Conference of Agronomy, Agron. Dept. Fac.Agric., Assuit Univ.,Nov:15-16 P:265-283.

Zayed B. A.; A.M.El Ekhtyar; A. B.El Abd and M.A. Badawi, (2006). Response of hybrid and inbred rice varieties to various nitrogen levels under saline soil conditions .J.Agric.,Sci., Mansoura Unversity :31(12)7497-7509.

Zayed, B.A.; A.K.M. Salem and 1H.M. El Sharkawy, (2011). Effect of Different Micronutrient Treatments on Rice(Oriza sativa L.) Growth and Yield under Saline Soil Conditions. World Journal of Agricultural Sciences 7 (2): 179-184. 
تأير صور و معدلات النيتروجين على التيسر لبعض العناصر الثقيلة وإنتاجية الأرز

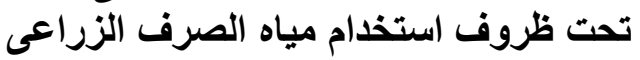

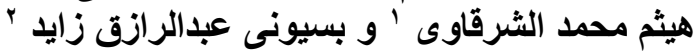

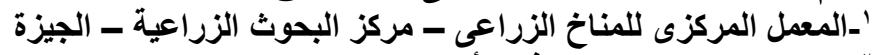

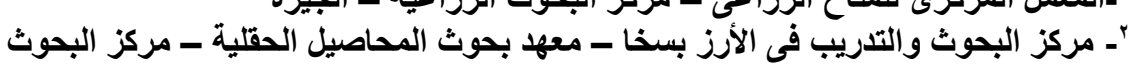

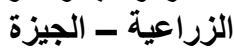

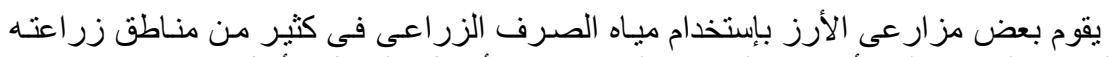

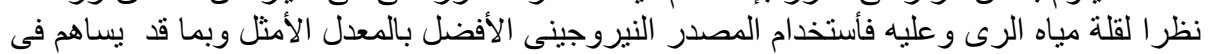

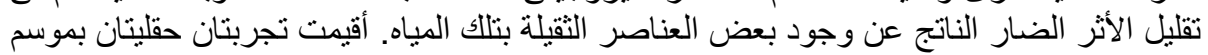

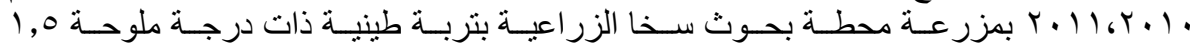

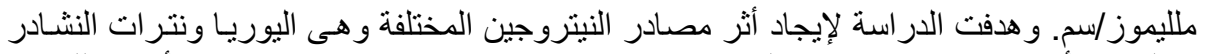

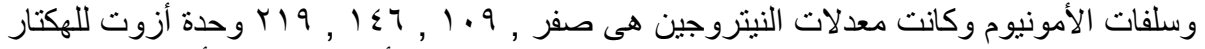

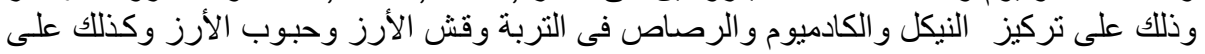

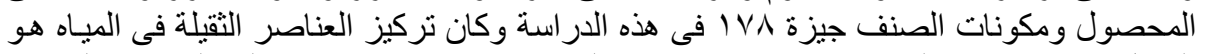

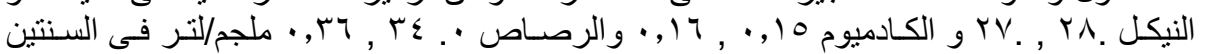

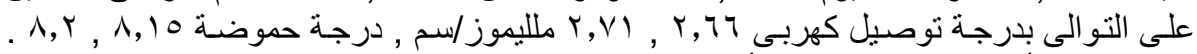

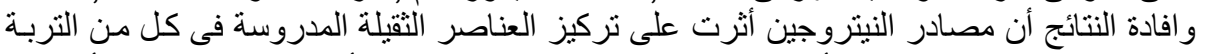

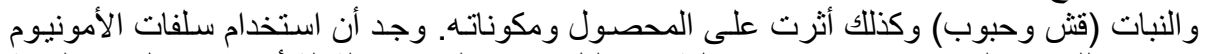

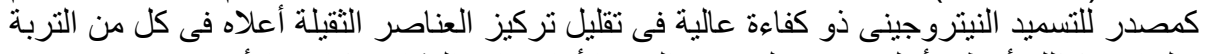

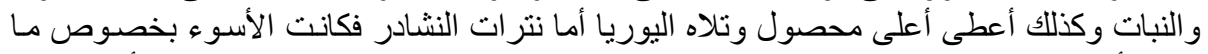

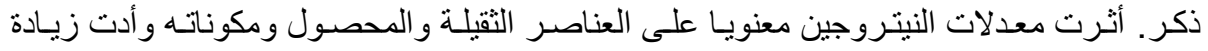

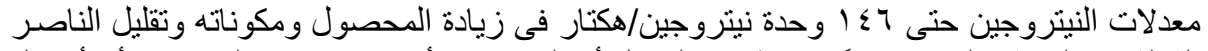

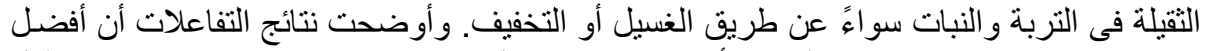

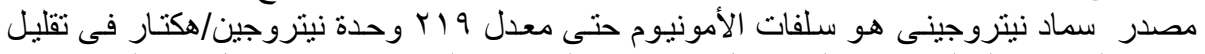

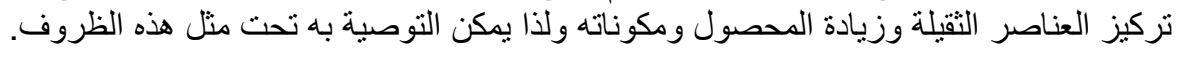

كلية الزراعة-جامعة المنصورة مركز البحوث الزراعية

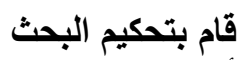

أ.دام/ عبد الرحيم عبد عبد الرحيم ليله

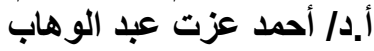

